\title{
Serovars, auxotypes, and plasmid profiles of PPNG strains with Asian type plasmid isolated in Amsterdam
}

\author{
M C ANSINK-SCHIPPER, * S M BYGDEMAN, $†$ B VAN KLINGEREN, $;$ \\ E G SANDSTRÖM $\S$ \\ From the *Municipal Health Service, Amsterdam, The Netherlands; the †Department of Clinical Bacteriology', \\ Huddinge University Hospital, Karolinska Institute, Stockholm, Sweden; the $\ddagger_{\ddagger}$ National Institute of Public \\ Health, Bilthoven, The Netherlands; and the §Department of Venereology', Södersjukhuset, Karolinska Institute, \\ Stockholm, Sweden
}

SUMMARY In 1982 an increase of penicillinase producing strains of Neisseria gonorrhoeae (PPNG), carrying the 4. 5 megadalton Asian type plasmid and the 24 megadalton transfer plasmid (Asia ${ }^{+}$), was observed in Amsterdam. The main auxotypes were proline requiring (Pro ${ }^{-}$) and proline and hypoxanthine requiring ( Pro $^{-} \mathrm{Hyx}^{-}$). Using two monoclonal antibody systems, it was shown that the serovars of strains with these auxotypes isolated in 1981 were different from those isolated in 1982, which indicated the start and end of microepidemics. Different serovars were also observed in Pro ${ }^{-}$ and non-requiring (NR) Asia ${ }^{-}$PPNG strains isolated in 1981-2 and 1985 respectively. Only one serovar (Aedih/Arst) was common in strains isolated in 1981-2 as well as in 1985.

An outbreak of infection with $\beta$ lactamase producing Neisseria gonorrhoeae (PPNG) strains in Amsterdam in 1981-2 caused by strains harbouring the $3 \cdot 2$ megadalton plasmid, with $\left(\mathrm{Afr}^{+}\right)$or without $\left(\mathrm{Afr}^{-}\right)$ the 24 megadalton transfer plasmid has been analysed by auxanographic typing' and serological classification. ${ }^{2}$

In 1982 an increase in PPNG strains with the 4.5 and 24 megadalton plasmids ( $\mathrm{Asia}^{+}$) was observed in Amsterdam. From March 1981 to October 1982 the $\mathrm{Asia}^{+}$strains isolated required mainly proline ( $\left.\mathrm{Pro}^{-}\right)$ or proline and hypoxanthine $\left(\mathrm{Pro}^{-} \mathrm{Hyx}^{-}\right)$. The Pro $^{-} \mathrm{Hyx}^{-}$PPNG strains were isolated in clusters. Four other auxotypes accounted for 23 of the Asia ${ }^{+}$ strains, of which 18 were non-requiring (NR). To assess whether the predominant PPNG strains of the same plasmid content and auxotype could be subdivided into different serovars ${ }^{3}$ and if the serovars of strains isolated in 1982 were the same as those isolated in 1981, a representative sample of these PPNG strains were classified serologically.

Pro $^{-}$and NR PPNG strains with the 4.5 megadalton plasmid but without the transfer plasmid $\left(\mathrm{Asia}^{-}\right)$ isolated in 1981-2 were also compared with those isolated in 1985 for their serovar distribution.

Address for reprints:Dr M C Ansink-Schipper, Municipal Health Service, PO Box 20244, 1000 HE Amsterdam, The Netherlands

Accepted for publication 8 November 1987

\section{Materials and methods}

PPNG STRAINS

We studied 119 out of 129 Pro $^{-}$and 39 out of 43 $\mathrm{Pro}^{-} \mathrm{Hyx}^{-}$Asia ${ }^{+}$PPNG strains isolated from March 1981 to October 1982 in Amsterdam. We also analysed $54 \mathrm{Pro}^{-}$and nine NR out of $68 \mathrm{Asia}^{-}$PPNG strains isolated in Amsterdam in 1981-2, as well as 44 Pro $^{-}$ and $24 \mathrm{NR}$ out of $135 \mathrm{Asia}^{-}$PPNG strains isolated in the same city in 1985.

\section{METHODS}

Assessment of $\beta$ lactamase production, plasmid profiles, and auxanotypes has been described earlier. ${ }^{14}$ A strain was considered to require hypoxanthine only if the repeatability of the hypoxanthine requirement was proved. Each batch of media was validated using a reference set of eight strains, two of which had a constant hypoxanthine requirement. The $\mathrm{Pro}^{-} \mathrm{Hyx}^{-}$ strains were tested three times, and if the requirement for hypoxanthine was lost after the second or third typing the strain was considered to be $\mathrm{Pro}^{-}$. Prostrains were repeat tested once. We did not find an additional hypoxanthine requirement during repeat testing.

Serological classification into serovars was performed as described by Bygdeman et al using two different sets of monoclonal antibodies, the GS antibodies (provided by Syva, Palo Alto, USA) and 
Table 1 GS/Ph serovar combinations of $\beta$ lactamase producing gonococcal strains with the 4.5 megadalton and 24 megadalton transfer plasmids $\left(\mathrm{Asia}^{+}\right)$related to auxotype and year of isolation

\begin{tabular}{|c|c|c|c|c|}
\hline \multirow{2}{*}{$\begin{array}{l}\text { Serovar } \\
\text { GS/Ph }\end{array}$} & \multicolumn{2}{|c|}{ No of Pro- strains isolated in: } & \multicolumn{2}{|c|}{$\begin{array}{l}\text { No of } \text { Pro }^{-} \mathrm{Hyx}^{-} \\
\text {strains isolated in: }\end{array}$} \\
\hline & 1981 & 1982 & 1981 & 1982 \\
\hline $\begin{array}{l}\text { WI: } \\
\text { Ae/Av } \\
\text { Adih/Arst }\end{array}$ & $\begin{array}{l}1 \\
0\end{array}$ & $\begin{array}{l}2 \\
1\end{array}$ & $\begin{array}{l}5 \\
0\end{array}$ & $\begin{array}{l}0 \\
0\end{array}$ \\
\hline $\begin{array}{l}\text { WII/WIII: } \\
\text { Bak/Bropyst } \\
\text { Bajk/Bropt } \\
\text { Bajk/Bopt } \\
\text { Bcgk/Bpyst } \\
\text { Bcegjk/Bpyust } \\
\text { Bcgj/Bopst }\end{array}$ & $\begin{array}{l}1 \\
1 \\
0 \\
0 \\
9 \\
2\end{array}$ & $\begin{array}{r}0 \\
0 \\
97 \\
2 \\
2 \\
1\end{array}$ & $\begin{array}{r}13 \\
0 \\
0 \\
0 \\
0 \\
0\end{array}$ & $\begin{array}{r}1 \\
0 \\
20 \\
0 \\
0 \\
0\end{array}$ \\
\hline Total & 14 & 105 & 18 & 21 \\
\hline
\end{tabular}

$\mathrm{Pro}^{-}=$Proline requiring; $\mathrm{Hyx}^{-}=$hypoxanthine requiring.

the $\mathrm{Ph}$ antibodies provided by Pharmacia Diagnostics AB, Uppsala, Sweden). ${ }^{3}$ For clarity the serovar designation used by Knapp et al has not been included in our tables. (For comparison see table 3 of Bygdeman et al. ${ }^{3}$ )

\section{Results}

\section{CHANGES BETWEEN 1981 AND 1982}

\section{Serovars of $\mathrm{Asia}^{+}$PPNG strains}

Table 1 shows that most $\mathrm{Pro}^{-}$and $\mathrm{Pro}^{-} \mathrm{Hyx}^{-}$strains belonged to serogroup WII/WIII. In 1981 nine of the $14 \mathrm{Pro}^{-}$strains belonged to the serovar combination Bcegjk/Bpyust in contrast to only two of the 105 strains with the same plasmid type and auxotype isolated in 1982. In 1982 the dominant serovar combination among these strains was Bajk/Bopt, which accounted for 97 of the 105 strains compared with none of the 14 strains isolated in 1981. A few strains of the serovar combinations $\mathrm{Ae} / \mathrm{Av}$ and Bcgjk/Bopst were seen in both years, and another four serovar combinations were represented by strains isolated in either 1981 or 1982.

The $18 \mathrm{Pro}^{-} \mathrm{Hyx}^{-}$strains isolated in 1981 were represented by only two serovar combinations, of which Bak/Bropyst accounted for 13. This serovar combination was seen in only one of the $21 \mathrm{Pro}^{-} \mathrm{Hyx}^{-}$ strains isolated in 1982. The remaining 20 strains belonged to the serovar combination Bajk/Bopt, which also dominated in the $\mathrm{Pro}^{-}$strains in the same year.

\section{Serovars of Asia ${ }^{-}$PPNG strains}

Table 2 shows great variety in the $\mathrm{Asia}^{-} \mathrm{Pro}^{-}$strains. Most (16) of the 25 strains isolated in 1981 and most (23) of the 29 strains isolated in 1982 belonged to the
Table $2 G S / P h$ serovar combinations of $\beta$ lactamase producing gonococcal strains with the 4.5 megadalton plasmid but without the 24 megadalton transfer plasmids (Asia ${ }^{-}$) related to auxotype and year of isolation

\begin{tabular}{|c|c|c|c|c|}
\hline \multirow{2}{*}{$\begin{array}{l}\text { Serovar } \\
\text { GS/Ph }\end{array}$} & \multicolumn{2}{|c|}{ No of $\mathrm{Pro}^{-}$strains isolated in: } & \multicolumn{2}{|c|}{$\begin{array}{l}\text { No of NR strains } \\
\text { isolated in: }\end{array}$} \\
\hline & $\overline{1981}$ & 1982 & 1981 & 1982 \\
\hline $\begin{array}{l}\text { WI: } \\
\text { Aedih/Arst } \\
\text { Aedi/Arst } \\
\text { Aedg/Ao } \\
\text { Aedg/Arst }\end{array}$ & $\begin{array}{r}16 \\
1 \\
0 \\
0\end{array}$ & $\begin{array}{r}23 \\
0 \\
1 \\
1\end{array}$ & $\begin{array}{l}0 \\
0 \\
0 \\
0\end{array}$ & $\begin{array}{l}1 \\
0 \\
0 \\
0\end{array}$ \\
\hline $\begin{array}{l}\text { WII/WIII: } \\
\text { Bcgjk/Bopst } \\
\text { Bcegjk/Bpyust } \\
\text { Bcejk/Bys } \\
\text { Bcgk/Bpyst } \\
\text { Bcgk/Bopst } \\
\text { Bcjk/Bopst } \\
\text { Bgjk/Bopst }\end{array}$ & $\begin{array}{l}3 \\
1 \\
1 \\
1 \\
1 \\
1 \\
0\end{array}$ & $\begin{array}{l}1 \\
3 \\
0 \\
0 \\
0 \\
0 \\
0\end{array}$ & $\begin{array}{l}1 \\
0 \\
0 \\
0 \\
0 \\
0 \\
0\end{array}$ & $\begin{array}{l}6 \\
0 \\
0 \\
0 \\
0 \\
0 \\
1\end{array}$ \\
\hline Total & 25 & 29 & 1 & 8 \\
\hline
\end{tabular}

Pro $^{-}=$proline requiring; $\mathrm{NR}=$ non-requiring.

WI serovar combination Aedih/Arst. In 1981 only one strain belonged to another WI serovar, and eight strains belonged to six WII/WIII serovars. In 1982 four Pro ${ }^{-}$strains belonged to two different WII/WIII serovars that had already been seen in 1981 .

The numbers of Asia ${ }^{-}$NR strains in 1981 and 1982 were small. The only NR strain isolated in 1981, and six of the eight strains in 1982, belonged to the WII/ WIII serovar Bcgjk/Bopst, which was also represented in the Pro- strains in 1981 and 1982.

\section{CHANGES BETWEEN 1981-2 AND 1985 IN ASIA $^{-}$} STRAINS

Table 3 shows that the Aedih/Arst serovar dominated $(12 / 44)$ in the Pro $^{-}$strains isolated in 1985, although not so much as in 1981-2 (39/54).

In 198530 of the Pro ${ }^{-}$strains belonged to seven different WII/WIII serovars, of which Bak/Bopyt (11), Bajk/Bropt (8), and Bgk/Bopyst (6) were the most common. Only one of the WII/WIII serovar combinations seen in the Pro $^{-}$strains was represented in both 1981-2 and 1985, in each period only by one strain.

The three most common serovar combinations in the 24 NR strains isolated in 1985, Back/Bropyst (13), Bacejk/Bpyst (6), and Bacejk/Brpyust (4), were not seen in the NR strains isolated in 1981-2 or in the $\mathrm{Pro}^{-}$ strains isolated in 1981-2 or 1985.

\section{COMPARISON BETWEEN SEROVARS OF ASIA ${ }^{+}$AND}

Asia ${ }^{-}$STRAINS

The most common WI serovar in the Asia ${ }^{+}$strains (Ae/Av) (table 1) was not seen in the $\mathrm{Asia}^{-}$strains (tables 2 and 3), and the dominant WI serovar in the 
Table 3 GS/Ph serovar combination of $\beta$ lactamase producing gonococcal strains with the 4.5 megadalton plasmid and without the 24 megadalton transfer plasmid (Asia ${ }^{-}$) related to auxotype and year of isolation

\begin{tabular}{|c|c|c|c|c|}
\hline \multirow{2}{*}{$\begin{array}{l}\text { Serovar } \\
\text { GS/Ph }\end{array}$} & \multicolumn{2}{|c|}{ No of $\mathrm{Pro}^{-}$strains isolated in: } & \multicolumn{2}{|c|}{$\begin{array}{l}\text { No of NR strains } \\
\text { isolated in: }\end{array}$} \\
\hline & $1981-2$ & 1985 & $1981-2$ & 1985 \\
\hline $\begin{array}{l}\text { WI: } \\
\text { Aedih/Arst } \\
\text { Other Protein IA }\end{array}$ & $\begin{array}{r}39 \\
3\end{array}$ & $\begin{array}{r}12 \\
2\end{array}$ & $\begin{array}{l}1 \\
0\end{array}$ & $\begin{array}{l}\mathbf{0} \\
\mathbf{0}\end{array}$ \\
\hline $\begin{array}{l}\text { WII/WIII: } \\
\text { Back/Bropyst } \\
\text { Bak/Bopyt } \\
\text { Bajk/Bropt } \\
\text { Bacejk/Bpyst } \\
\text { Bacejk/Brpyust } \\
\text { Bcegjk/Bpyust } \\
\text { Bcgjk/Bopst } \\
\text { Bgk/Bopyst } \\
\text { Other Protein IB }\end{array}$ & $\begin{array}{l}0 \\
0 \\
0 \\
0 \\
0 \\
4 \\
4 \\
0 \\
4\end{array}$ & $\begin{array}{r}0 \\
11 \\
8 \\
0 \\
0 \\
0 \\
0 \\
6 \\
5\end{array}$ & $\begin{array}{l}0 \\
0 \\
0 \\
0 \\
0 \\
0 \\
7 \\
0 \\
1\end{array}$ & $\begin{array}{r}13 \\
0 \\
0 \\
6 \\
4 \\
0 \\
0 \\
0 \\
1\end{array}$ \\
\hline Total & 54 & 44 & 9 & 24 \\
\hline
\end{tabular}

Pro = proline requiring; $\mathrm{NR}=$ non-requiring; Protein $\mathrm{IA}=\mathrm{WI}$; Protein IB = WII/III.

Asia $^{-}$strains (Aedih/Arst) was not seen in the Asia $^{+}$ strains.

Only four of the 17 WII/WIII serovars were represented in both $\mathrm{Asia}^{+}$and Asia ${ }^{-}$strains. Bcegjk/ Bpyust, the dominant serovar in $\mathrm{Asia}^{+} \mathrm{Pro}^{-}$strains isolated in 1981 (table 1) was also seen in Asia ${ }^{-}$strains (table 2) of the same auxotype isolated in 1981. Bcgjk/ Bopst, the dominant serovar in Asia- NR strains, was also seen in $\mathrm{Pro}^{-}$strains with and without the transfer plasmid. Bajk/Bropt and Bcgk/Bpyst were also represented by a few strains either with or without the transfer plasmid.

\section{Discussion}

All strains were typable with the $\mathrm{Ph}$ reagents and all except one with the GS reagents. This non-reacting Asia $^{-}$Pro $^{-}$strain, isolated in 1985 , belonged to the $\mathrm{Ph}$ serovar Ar. Mostly one serovar of one system corresponded with one or two serovars of the other system. For example, when one GS serovar corresponded with two or more $\mathrm{Ph}$ serovars, the two $\mathrm{Ph}$ serovars were closely related in that they differed by only one or two reactions (table 1, Bajk/Bropt and Bajk/Bopt; table 3, Bacejk/Bpyst and Bacejk/Brpyust). This might be the result of antigenic drift of gonococcal protein. ${ }^{5}$

New serovars appeared and disappeared, which indicated the introduction of new clones and the end of microepidemics. The Bak/Bropyst serovar isolated in 1981 had almost disappeared in 1982, and the Bajk/ Bopt serovar was not found in 1981 (table 1). The Bcgjk/Bopst serovar identified in 1981 and 1982 was not isolated in 1985, and the Bak/Bopyt, Bajk/Bropt, and Back/Bropyst serovars were only seen in 1985 (tables 2 and 3).

Except for Aedih/Arst, therefore, different serovar combinations predominated in $\mathrm{Asia}^{+}$as well as $\mathrm{Asia}^{-}$ strains during different periods and then more or less disappeared. The finding of Aedih/Arst strains in both 1981-2 and 1985 may be due to a superior capacity to survive and be transmitted compared with strains of the WII/WIII serovars or may have resulted from repeated importation of PPNG strains of this type from places such as South East Asia, where this serovar is dominant in WI strains. ${ }^{6}$

During a PPNG outbreak in Amsterdam in 1980-1 caused mainly by $\mathrm{Afr}^{+}$strains, the dominant serovar was $\mathrm{Ae} / \mathrm{Av}^{2}{ }^{2}$ We concluded that strains of this serovar combination also seem to have a great capacity to survive and be transmitted. As Aedih/Arst and Ae/Av belong to the three dominant WI serovar combinations world wide, strains of established WI serovars may be better equipped for survival than strains of certain WII/WIII serovars.

The finding of the same serovar and auxotype (Bcegjk/Bpyust/Pro ${ }^{-}$and Bcgjk/Bopst/Pro ${ }^{-}$) in Asia ${ }^{+}$ as well as $\mathrm{Asia}^{-}$strains might implicate the loss or acquisition of the transfer plasmid in these strains.

In $1981 \mathrm{Asia}^{+} \mathrm{Pro}^{-} \mathrm{Hyx}^{-}$strains of the Bak/Bropyst serovar combination were found during a short period. Most Asia ${ }^{+} \mathrm{Pro}^{-} \mathrm{Hyx}^{-}$strains isolated in 1982 belonged to the serovar combination Bajk/Bopt as did most of the Pro ${ }^{-}$strains. Reversions of hypoxanthine requirement might have occurred within $\mathrm{Asia}^{+}$strains of the serovar combination Bajk/Bopt. Mayer et al have described such a reversion.?

Knapp et al concluded from a study of 425 gonococcal isolates isolated from 390 patients that the auxotype/serovar classification system can be used to trace the introduction and spread of gonococcal strains and their eventual elimination from a community. ${ }^{8}$ Our results confirm this view. We conclude that plasmid characterisation and auxonographic typing in combination with serological classification into serovars are important tools in the surveillance and understanding of outbreaks of infection with PPNG strains.

This work was supported by a grant (No 28-892) from the "Praeventiefonds" of The Netherlands. We thank Mesdames M H Huikeshoven, M Dessens-Kroon, and $M$ Verheuvel and Mr R Gerritzen for their skilful technical help and Mrs $\mathrm{H}$ A de Jongh for typing the manuscript.

\section{References}

1 Ansink-Schipper MC, Huiskeshoven MH, Woudstra RK, et al. Epidemiology of PPNG infections in Amsterdam. British Journal of Venereal Diseases 1984;60:23-8.

2 Ansink-Schipper MC, Bygdeman SM, van Klingeren B, Sand- 
ström EG. Serovars, auxotypes, and plasmid contents of PPNG strains from outbreak in Amsterdam. Genitourin Med 1987;63:157-9.

3 Bygdeman SM, Gillenius EC, Sandström EG. A comparison between two different sets of monoclonal antibodies for the serological classification of Neisseria gonorrhoeae. In: Schoolnik GK, Brooks G, Falkow JS, Knapp JS, McCutchan A, Morse S, eds. The pathogenic neisseriae. Washington DC: American Society of Microbiology, 1985:31-6.

4 van Klingeren B, van Wijngaarden LJ, Dessens-Kroon M, van Embden JDA. Penicillinase producing gonococci in The Netherlands in 1981. J Antimicrob Chemother 1983;11:15-20.

5 Sandström EG, Tam M, Bygdeman SM. Antigenic drift of gonococcal Protein I as judged by serovar determination. In:
Schoolnik GK, Brooks G, Falkow JS, Knapp JS, McCutchan A, Morse S, eds. The pathogenic neisseriae. Washington DC: American Society of Microbiology, 1985:4-5.

6 Bygdeman SM. Polyclonal and monoclonal antibodies applied to the epidemiology of gonococcal infection. In: Young $\mathbf{H}$, McMillan A, eds. Immunological diagnosis of sexually transmitted diseases. New York: Marcel Decker, 1987:117-65.

7 Mayer LW, Schoolnik GK, Falkow S. Genetic studies on Neisseria gonorrhoeae from disseminated gonococcal infections. Infect Immun 1977;18:165-72.

8 Knapp JS, Holmes KK, Bonin P, Hook EW. Epidemiology of gonorrhoea: distribution and temporal changes in auxotype/ serovar classes of Neisseria gonorrhoeae. Sex Transm Dis 1987;14:26-32. 